\title{
Impact of Merger on Operational and HR Efficiency: A Case Study of the State Bank of India
}

\author{
Sanjana S. Shenoy ${ }^{1} \&$ Shailashri V. T. ${ }^{2}$ \\ ${ }^{1}$ Research Scholar, College of Management and Commerce, Srinivas University, \\ Mangaluru- 575001, India \\ OrcidID: 0000-0002-4415-1084; Email: sanjanashenoy.cmc@ srinivasuniversity.edu.in \\ ${ }^{2}$ Research Professor, College of Management and Commerce, Srinivas University, \\ Mangaluru- 575001, India \\ OrcidID: 0000-0002-1684-238X; E-mail: shailashrivt@gmail.com
}

Area of the Paper: Business Management.

Type of the Paper: Research Case Study.

Type of Review: Peer Reviewed as per $|\mathrm{C}| \mathrm{O}|\mathrm{P}| \mathrm{E} \mid$ guidance.

Indexed In: OpenAIRE.

DOI: https://doi.org/10.5281/zenodo.5235286

Google Scholar Citation: IJCSBE

\section{How to Cite this Paper:}

Shenoy, Sanjana S., \& Shailashri, V. T. (2021). Impact of Merger on Operational and HR Efficiency: A Case Study of the State Bank of India. International Journal of Case Studies in Business, IT, and Education (IJCSBE), 5(2), 87-99. DOI: https://doi.org/10.5281/zenodo.5235286

International Journal of Case Studies in Business, IT and Education (IJCSBE)

A Refereed International Journal of Srinivas University, India.

Crossref DOI : https://doi.org/10.47992/IJCSBE.2581.6942.0122

(C) With Authors.

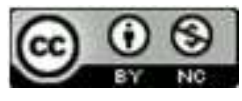

This work is licensed under a Creative Commons Attribution Non-Commercial 4.0 International License subject to proper citation to the publication source of the work.

Disclaimer: The scholarly papers as reviewed and published by the Srinivas Publications (S.P.), India are the views and opinions of their respective authors and are not the views or opinions of the S.P. The S.P. disclaims of any harm or loss caused due to the published content to any party. 


\title{
Impact of Merger on Operational and HR Efficiency: A Case Study of the State Bank of India
}

\author{
Sanjana S. Shenoy ${ }^{1} \&$ Shailashri V. T. ${ }^{2}$ \\ ${ }^{1}$ Research Scholar, College of Management and Commerce, Srinivas University, \\ Mangaluru- 575001, India \\ OrcidID: 0000-0002-4415-1084; Email: sanjanashenoy.cmc@ srinivasuniversity.edu.in \\ ${ }^{2}$ Research Professor, College of Management and Commerce, Srinivas University, \\ Mangaluru- 575001, India \\ OrcidID: 0000-0002-1684-238X; E-mail: shailashrivt@ gmail.com
}

\begin{abstract}
Purpose: Analysing financial performance is one of the popular methods for measuring operational efficiency of a firm. Ratio analysis is an important tool of financial analysis. The analysis of key performance parameters enables diverse group of stakeholders to obtain information about profitability and growth prospects. Mergers and acquisitions are popular means of inorganic growth. The Indian Banking Industry has used this effective tool to consolidate and grow in size. Through $M \& A$, acquired banks get a new name, structure, products and services. However, the risk of NPAs continues to be a major problem for banks. In order to study the effectiveness of a merger, analysing financial performance prior to and after merger becomes important. The State Bank of India merger has been taken up for the study, since following the merger there is a substantial increase in both the market share as well as asset base of the bank.
\end{abstract}

Design/Methodology/Approach: This paper studies the result of mergers on financial indicators, market performance, asset quality, liquidity position and employee productivity of SBI after it merged with its 5 associate banks and BMB through ratio analysis. The ratios indicating the performance parameters have been taken from secondary sources such as moneycontrol.com, stock-financials.valuestocks.in. etc. A comparison of various financial ratios is made to determine the change in the performance parameters of the bank.

Findings/Result: The study highlights reduction in profitability, increase in cost to income ratio, slight improvement in liquidity, decline in asset quality and market performance and a slight decrease in employee productivity after the merger.

Originality/Value: This paper studies the effectiveness of mergers in terms of change in key financial performance parameters.

Paper Type: Research Case Study based on company financial analysis.

Keywords: Bank Mergers, State Bank of India, Financial Performance, Market Performance, Ratio Analysis, Non-Performing Assets, Employee Productivity.

\section{INTRODUCTION :}

Mergers and acquisitions are effective strategies for achieving growth and expansion for businesses, world over. Mergers enable companies to raise fresh capital, improve efficiency, increase value for shareholders and enable the firm to attract better talent. They also help cut costs, create synergies and economies of scale, improve their market share and meet competitive challenges. Indian corporates have also adopted this inorganic route of M\&A to achieve growth and gain a competitive advantage. Removal of the restrictive provisions of the MRTP Act and reforms in FEMA and FERA in 2000 has encouraged and increased M\&A activities not only within the country but also cross-border M\&As. The banking industry of the country is the main stay of our financial system, playing an important role in mobilising funds and channelling investments to the economy. According to a report by IBEF [1], "The Indian banking system comprises 12 public sector banks, 22 private sector banks, 56 RRBs, 1485 urban co-operative banks". 
The financial inclusion initiatives of the government have enabled several people to access banking services. As in April 2020, deposits under the PMJDY stood at Rs. 1.28 lakh crores There is an increased use of digital payments, especially after UPI was introduced. At the end of March 2020, total transactions under the UPI were recorded at 1.25 billion valued at 2.06 lakh crores [2]. As in 2020, there are 38.7 crore Jan Dhan accounts [3]. Simultaneously, the banking industry faces several challenges. The poor asset quality due to massive Non-productive Assets (NPAs) and large overdues has been a persistent problem faced by the Indian banks. The banking system has had to face large defaults in recent times. In the Indian banking scenario, mergers have strengthened the weaker banks. It has also enabled acquiring banks to grow in size.

State Bank of India (SBI) is the leading bank of the country in terms of deposits, advances, number of customers and number of bank branches. It is the largest Public Sector Bank in terms of market capitalisation. The SBI differs from other commercial banks in the sense that it acts as the agent of the Reserve Bank of India in such places where it has no branches. One of it's main objectives is to follow the economic policy guidelines of the Government in it's working. According to a study, "The SBI has become one of the top 50 Global Banks after the merger. After its merger, it has a total of 24,017 bank branches and the number of is ATMs have increased to 59,263 and customer base to 42-crore and market share increased to $22.5 \%$ from 17\%" [4]. However, the risks of mergers of banks include high NPAs and costs related to the merger.

\section{RELATED WORKS :}

Edward, A. and Jyothi Manoj (2019) [5] studied the financial performance of SBI after its merger. The study also sought to analyse changes in the share prices of the bank. The study came to the conclusion that the merger has not brought about any notable change in the liquidity, profitability and operational performance of the bank. The announcement of the merger led to significantly positive abnormal returns on the share price of the bank.

Upadhyay, R. and Kurmi (2020) [6] analysed the performance of SBI after its merger using the CAMELS framework. The study finds that in all the parameters used to analyse performance such as Capital Adequacy, Asset Quality, Management Efficiency, Earnings Capacity, Liquidity and Sensitivity there has been no improvement. Among the Management Efficiency ratios only Business per Employee Ratio has shown an upward trend.

Kanungo et al. (2020) [7] studied the impact of monetary policies of the RBI on the efficiency of SBI in terms of liquidity and profitability. The study found that all the monetary policy measures adopted by the central bank had a significant impact on the net profits and cash deposits of SBI before and after the merger.

Dhara, P. and Basu, S., (2020) [8] studied the post-merger financial performance of SBI by observing changes in ratios such as RONW, ROA, ROCE, EPS and NPM. The study makes a forecast of the net profit position of SBI for the period up to 2025 and concludes that the net profit position of SBI will show an upward trend in the coming years.

Sharma and Patel (2019) [9] examined the financial performance of SBI by applying the CAMEL model and also compared the performance of the merging banks with each other. The study finds that in terms of capital adequacy SSSJ ranks first, SBP in terms of asset quality, SBH in terms of productivity, efficiency of human resources and quality of earnings.

Table 1: Review of related works on Mergers and Acquisitions

\begin{tabular}{|l|l|l|l|l|}
\hline Sl. No. & Period of study & Mergers studied & Findings & References \\
\hline 1 & $1979-83$ & $\begin{array}{l}\text { Fifty largest } \\
\text { acquisitions in the US } \\
\text { listed in NYSE. }\end{array}$ & $\begin{array}{l}\text { Significant improvement } \\
\text { was found in the } \\
\text { operating performance of } \\
\text { acquiring firm; post- } \\
\text { merger. }\end{array}$ & $\begin{array}{l}\text { Healy, Palepu } \\
\text { and Ruback, } \\
\text { (1992). [10] }\end{array}$ \\
\hline 2 & $1999-2003$ & $\begin{array}{l}118 \text { cases of mergers } \\
\text { in various Indian } \\
\text { industries }\end{array}$ & $\begin{array}{l}\text { In case of banking and } \\
\text { finance, pharma, textile } \\
\text { and Electric equipment } \\
\text { sectors an improvement }\end{array}$ & $\begin{array}{l}\text { Mantravadi and } \\
\text { Reddy, (2008). } \\
{[11]}\end{array}$ \\
\hline
\end{tabular}




\begin{tabular}{|c|c|c|c|c|}
\hline & & & $\begin{array}{l}\text { in profitability was } \\
\text { found. } \\
\text { A significant decline was } \\
\text { observed in the chemical } \\
\text { and agri- sector. }\end{array}$ & \\
\hline 3 & $\begin{array}{ll}2010-11 & \text { to } \\
2015-16 & \end{array}$ & 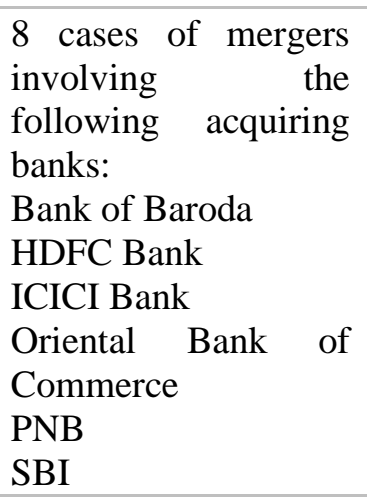 & $\begin{array}{l}\text { In the case of BoB, OBC } \\
\text { and PNB, the current } \\
\text { ratio shows no } \\
\text { improvement after the } \\
\text { merger. SBI recorded an } \\
\text { improvement in } \\
\text { converting working } \\
\text { capital to } \\
\text { earnings. ROCE has not } \\
\text { been impacted much in } \\
\text { any bank. }\end{array}$ & $\begin{array}{l}\text { Singh and Das, } \\
(2008) .[12]\end{array}$ \\
\hline 4 & $\begin{array}{l}\text { 2005-07 (pre- } \\
\text { merger) } \\
\& \quad 2009-11 \\
\text { (post-merger) }\end{array}$ & $\begin{array}{l}2 \text { bank mergers } \\
\text { HDFC bank with } \\
\text { Centurion Bank of } \\
\text { Punjab } \\
\text { Centurion Bank of } \\
\text { Punjab with Lord } \\
\text { Krishna Bank }\end{array}$ & $\begin{array}{l}\text { No change in net profit } \\
\text { margin, ROCE and } \\
\text { operating profit margin } \\
\text { after the merger. Debt- } \\
\text { equity ratio shows } \\
\text { improvement post- } \\
\text { merger. }\end{array}$ & $\begin{array}{l}\text { Devarajappa S., } \\
\text { (2012). [13] }\end{array}$ \\
\hline 5. & 2004- 2009 & $\begin{array}{lr}\text { Indian bank } & \text { mergers } \\
\text { occurring } & \text { during } \\
2004-2009 & \end{array}$ & $\begin{array}{l}\text { Technical efficiency of } \\
\text { merged banks showed } \\
\text { improvement only from } \\
\text { the } 3^{\text {rd }} \text { year since merger. } \\
\text { The underperformance of } \\
\text { merged banks is due to } \\
\text { scale inefficiency. } \\
\text { There was no significant } \\
\text { impact on profitability } \\
\text { and operational costs. }\end{array}$ & $\begin{array}{l}\text { Jayaraman, } \\
\text { Rangaswamy } \\
\text { and } \\
\text { Arunachalam, } \\
\text { (2014). [14] }\end{array}$ \\
\hline 6 & $\begin{array}{l}2006-10 \text { (pre- } \\
\text { merger) \& 2011- } \\
15 \text { (post-merger) }\end{array}$ & $\begin{array}{l}\text { SBI merger with State } \\
\text { bank of Indore }\end{array}$ & $\begin{array}{l}\text { The overall positive } \\
\text { impact on liquidity and } \\
\text { investment parameters } \\
\text { and negative impact on } \\
\text { profitability. }\end{array}$ & $\begin{array}{l}\text { Gupta, (2016). } \\
\text { [15] }\end{array}$ \\
\hline 7. & $\begin{array}{l}2007-10 \text { (pre- } \\
\text { merger) \& } 2010 \\
-\quad 17 \quad \text { (post- } \\
\text { merger) }\end{array}$ & ICICI bank merger & $\begin{array}{l}\text { Increase in profitability } \\
\text { and improvement in } \\
\text { liquidity position post- } \\
\text { merger. } \\
\text { EPS also increased post- } \\
\text { merger. }\end{array}$ & $\begin{array}{l}\text { Veena K.P., } \\
\text { (2016). [16] }\end{array}$ \\
\hline 8. & $\begin{array}{l}5 \text { years before } \\
\text { and after the } \\
\text { merger up to } \\
2014\end{array}$ & $\begin{array}{l}\text { Mergers involving the } \\
\text { following acquiring } \\
\text { banks: } \\
\text { Federal Bank } \\
\text { Indian Overseas bank } \\
\text { SBI } \\
\text { ICICI bank }\end{array}$ & $\begin{array}{l}\text { In case of ICICI bank, the } \\
\text { study found that the } \\
\text { performance } \\
\text { improved. } \\
\text { In case of IOB, Federal } \\
\text { Bank and SBI, } \\
\text { performance in terms } \\
\text { of CAR \& NPA and } \\
\text { liquidity has declined. }\end{array}$ & $\begin{array}{l}\text { Tanwar, (2016). } \\
\text { [17] }\end{array}$ \\
\hline
\end{tabular}




\begin{tabular}{|c|c|c|c|c|}
\hline 9. & $\begin{array}{l}2003-\quad 04 \text { till } \\
2013-14\end{array}$ & $\begin{array}{l}\text { Bank of Baroda } \\
\text { merger } \\
\text { Oriental bank of } \\
\text { commerce } \\
\text { IDBI Bank } \\
\text { SBI merger }\end{array}$ & $\begin{array}{l}\text { In case of BOB and OBC } \\
\text { negative impact on ROE, } \\
\text { ROA, Net profit ratio and } \\
\text { yield on investment. } \\
\text { Positive impact on EPS, } \\
\text { Profit/employee, } \\
\text { yield/employee. } \\
\text { In case of IDBI, merger } \\
\text { has had most adversely } \\
\text { impacted profitability. } \\
\begin{array}{l}\text { For SBI, all performance } \\
\text { parameters have } \\
\text { improved after the } \\
\text { merger. }\end{array}\end{array}$ & $\begin{array}{l}\text { Patel, (2018). } \\
\text { [18] }\end{array}$ \\
\hline 10. & $2015-18$ & $\begin{array}{l}\text { SBI merger with State } \\
\text { bank of Indore }\end{array}$ & $\begin{array}{l}\text { An improvement in } \\
\text { liquidity and decrease in } \\
\text { profitability and decline } \\
\text { in market performance } \\
\text { has been observed. }\end{array}$ & $\begin{array}{lr}\text { Manoj } & \text { Kumar } \\
\text { N.V., } & (2018) . \\
{[19]} & \end{array}$ \\
\hline 11. & $\begin{array}{ll}2013-14 & \text { to } \\
2017-18 & \end{array}$ & $\begin{array}{l}\text { SBI merger with } \\
\text { associate banks and } \\
\text { BMB. }\end{array}$ & $\begin{array}{l}\text { Reduction in cash- } \\
\text { deposit ratio and } \\
\text { investments. } \\
\text { Deposits to liability ratio } \\
\text { is stable. }\end{array}$ & $\begin{array}{l}\text { Sreemathi and } \\
\text { Tharmalingam, } \\
\text { (2018). [20] }\end{array}$ \\
\hline 12. & $\begin{array}{l}2004-09 \text { (pre- } \\
\text { merger) } \\
\& 2010-17 \text { (post- } \\
\text { merger) }\end{array}$ & $\begin{array}{l}\text { SBI merger with State } \\
\text { bank of Indore }\end{array}$ & $\begin{array}{l}\text { The cost of banking } \\
\text { operations has reduced. } \\
\text { Improvement in per- } \\
\text { branch performance. } \\
\text { No significant } \\
\text { improvement in per- } \\
\text { employee ratios. } \\
\text { All key ratios except cost } \\
\text { to income have shown a } \\
\text { decline in performance. }\end{array}$ & $\begin{array}{l}\text { Ali and Sharma } \\
\text { (2019). [21] }\end{array}$ \\
\hline
\end{tabular}

\subsection{Research Gap}

The present paper analyses not only the operational efficiency of SBI in terms of financial parameters such as liquidity, profitability, market performance and Asset Quality but also the impact of the merger on the efficiency of the workforce by studying Interest Income/ Employee, Business/ Employee, Net profit/Employee.

\section{OBJECTIVES :}

(1) To study the impact of the merger on profitability of SBI

(2) To analyse the liquidity position of SBI after the merger.

(3) To analyse the post-merger changes in the asset quality of SBI.

(4) To observe post-merger changes on the market performance of SBI.

(5) To observe the improvement, if any, in employee productivity of SBI post-merger.

\section{RESEARCH HYPOTHESES :}

The basic purpose of consolidation and restructuring is to obtain benefits of economies of scale, improved operational efficiency and better management of assets and control of costs.

In view of these challenges, the question arises as to whether, bank mergers can improve the quality of assets and provide a solution for managing NPAs and also in cutting costs and improving operational efficiency. 
In this context, the present study aims to analyze the pre- and post-merger performance of SBI to measure the impact of merger on its liquidity position, profitability, operational efficiency, market standing and asset quality.

- H0: No significant difference can be observed in the Net profit margin after the merger.

H1: Significant difference can be observed in the Net profit margin after the merger.

- Ho: No significant difference in the cost to income ratio of the bank under study post-merger. H2: Significant difference can be observed in the cost to income ratio of the bank under study post-merger.

- H0: EPS of SBI shows no significant difference after the merger.

H3: EPS of SBI shows a significant difference after the merger.

- H0: No significant difference is observed in the management of NPAs after the merger.

H4: A significant difference is observed in the management of NPAs after the merger.

- Ho: No significant difference is observed in the current ratio after the merger of the bank under study.

H5: A significant difference is observed in the current ratio after the merger of the bank under study.

- H0: No significant difference can be seen in the employee productivity of SBI following the merger.

H6: Significant difference can be seen in employee productivity of SBI following the merger.

\section{RESEARCH DESIGN :}

The case study of SBI merger is selected as this merger is an important move towards consolidation of the state-run banks. With this merger, $25 \%$ of outstanding loans in the country's banking sector will be found in SBI's balance sheet. Additionally, the merged entity will have 23,000 branches and a global presence [22].

\subsection{Methodology of Data Collection}

The data are collected from secondary sources. Various ratios are obtained from the following websites www.moneycontrol.com

stock-financials.valuestocks.in

Standalone balance sheet ratios of SBI i.e., the acquiring bank has been considered for the study.

\subsection{Period of Study}

The merger under study having taken place on $1^{\text {st }}$ April 2017, three financial years have since elapsed. Hence, data for a period of 6 financial years i.e., 3 years before the merger and 3 years after the merger for the acquiring bank has been considered.

\subsection{Research Tools}

Analysing financial statements, income statement, including revenues, cost of sales, gross margin, net margin etc. and balance sheet is important to know the financial risk of the bank [23-25]. According to a study [26], efficiency and productivity are important ways of measuring the robustness of the banking sector. Another study [27] has found that there is an inverse relationship between the size of the bank and productivity.

a) The pre- and post-merger profitability position is analysed using the ratios Return on Capital Employed (ROCE), Current Account Savings Account (CASA), Net Profit Margin, Operating Profit Margin, Return on Assets (ROA), Return on Equity (ROE)/Net worth, Net Interest Margin (NIM), Cost to Income.

b) The market performance is evaluated through Earnings Per Share (EPS) (Rs.), Price to Book Value, Earnings Yield and Price to Earnings (P/E) Ratio. 
c) The asset quality is measured through Net and Gross Non-Performing Assets (NPA) Ratio.

d) To analyse the liquidity position, financial ratios such as Current Ratio and Loans to Deposit are used.

e) Employee productivity is measured through 3 per employee ratios, viz, Net Profit/Employee, Interest Income/Employee and Business/Employee.

\subsection{Methodology of Data Interpretation}

The ratios are tabulated to observe the post-merger change. A comparison of the performance is done by calculating the means before and after the merger. T-test has been conducted to determine whether a significant change can be observed in the 6 years under study. The hypothesis has been tested at $5 \%$ level of significance.

\section{ANALYSIS AND INTERPRETATION :}

\subsection{Key Performance Ratios}

Table 2: Key performance indicators of SBI from 2014-15 to 2019-20

\begin{tabular}{|c|c|c|c|c|c|c|}
\hline & \multicolumn{2}{|c|}{ MEAN } & \multicolumn{2}{|c|}{ STD. DEV } & \multirow{2}{*}{$\begin{array}{l}\text { Mean } \\
\text { Difference }\end{array}$} & \multirow[t]{2}{*}{ p- value } \\
\hline & $\overline{\text { PRE }}$ & $\overline{\text { POST }}$ & PRE & POST & & \\
\hline ROCE & 2.003333333 & 1.2 & 0.051316014 & 1.039278596 & -0.8033333 & 0.252134921 \\
\hline CASA & 42.84 & 29.566667 & 1.627236922 & 25.60581444 & -13.273333 & 0.420882559 \\
\hline $\begin{array}{l}\text { Net Profit } \\
\text { margin }\end{array}$ & 6.87333333 & 1.0066667 & 1.487357836 & 4.332485815 & -5.8666667 & 0.090782988 \\
\hline $\begin{array}{l}\text { Operating } \\
\text { profit margin }\end{array}$ & -10.45 & -16.4233333 & 4.029739446 & 5.962451956 & -5.9733333 & 0.223906045 \\
\hline $\begin{array}{l}\text { Return on } \\
\text { Assets }\end{array}$ & 0.476666667 & 0.06666667 & 0.134288247 & 0.273007936 & -0.41 & 0.0798936 \\
\hline $\begin{array}{l}\text { Return on } \\
\text { Equity/Net } \\
\text { worth }\end{array}$ & 7.926666667 & 1.323333333 & 1.971302446 & 5.22292383 & -6.6033333 & 0.109845197 \\
\hline $\begin{array}{l}\text { Net interest } \\
\text { margin }\end{array}$ & 2.46 & 2.3466666667 & 0.202977831 & 0.16653328 & -0.1133333 & 0.496224158 \\
\hline $\begin{array}{ll}\text { Cost } & \text { to } \\
\text { Income } & \end{array}$ & 39.04666667 & 44.923333 & 2.151518843 & 2.483955179 & 5.87666667 & 0.036312239 \\
\hline
\end{tabular}

Source: www.moneycontrol.com and author's calculations

\section{KEY PERFORMANCE RATIOS}
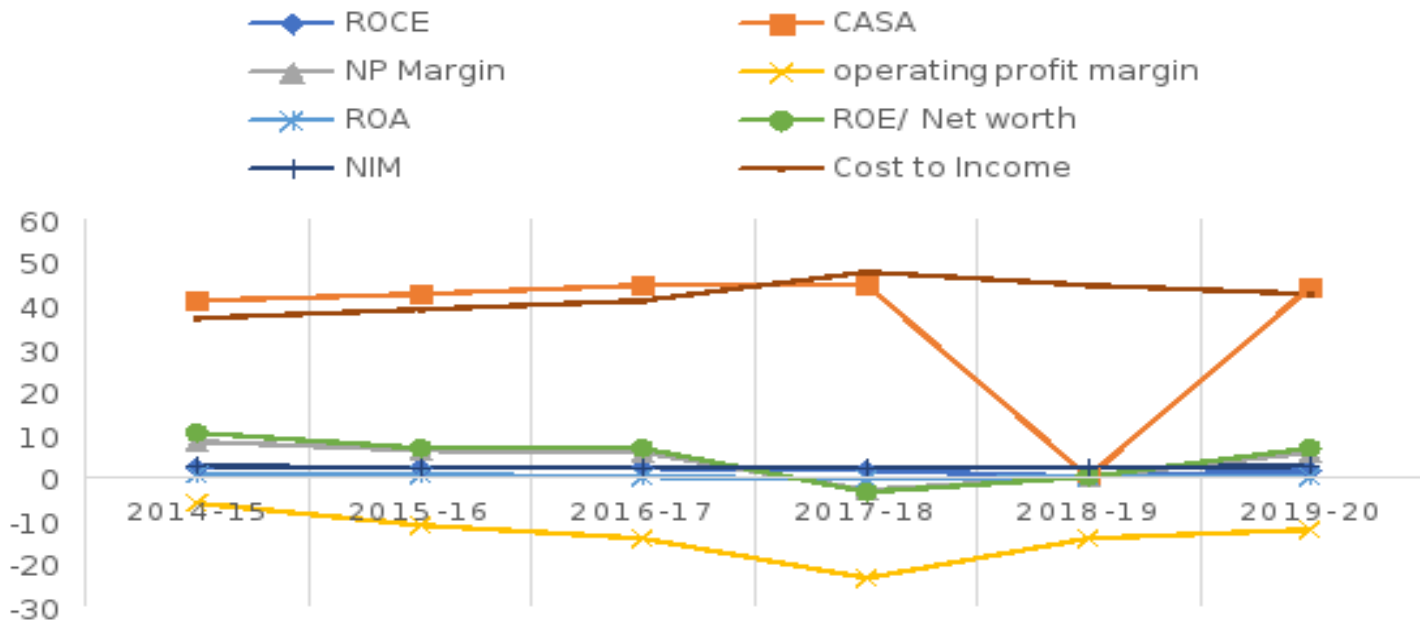

Fig. 1: Key Performance ratios of SBI 2014-15 to 2019-20 


\section{Interpretation}

- The ROCE has reduced post-merger, this fall shows that there is a decline in the bank's earnings on its investment. Since the p-value is $<0.05$, the decline is not statistically significant.

- A higher CASA means cost of funds is lower. As current accounts do not carry any interest and savings accounts get minimum interest, CASA has reduced in post-merger years meaning that costs of funds have increased. However, it is not statistically significant.

- The Net Profit margin has reduced post-merger, indicating a decrease in profitability postmerger. As observed from the table, the decline is not statistically significant.

Hence, the null hypothesis is accepted.

- The Operating Profit margin has reduced post-merger, indicating an increase in the cost of operations post-merger. Thus, there is no improvement in managing costs after the merger. However, the decrease in operational profit margin is not statistically significant.

- The return on assets has decreased post-merger, indicating that assets are not being properly utilised to earn returns. However, the decrease is not statistically significant.

- The Return on Net Worth/Equity has decreased post-merger, that means that profitability has declined from shareholder's perspective also. As observed from the table, the decline is not statistically significant.

- Net Interest Margin has declined post-merger. If the NPAs rise, the interest earned would come down, hence NIM will fall. NIM will also fall when the bank loans come down. So, reducing NIM post-merger implies investment inefficiency. However, the fall is not statistically significant.

- The cost to income ratio has increased in the post-merger years. It shows that costs are rising faster than income. Also, since $p<0.05$, the increase is statistically significant. Hence, the null hypothesis is rejected.

6.2. Market Performance Ratios

Table 3: Market performance indicators of SBI before and after the merger

\begin{tabular}{|c|c|c|c|c|c|c|}
\hline & \multicolumn{2}{|c|}{ MEAN } & \multicolumn{2}{|c|}{ STD. DEV. } & \multirow{2}{*}{$\begin{array}{l}\text { Mean } \\
\text { Difference }\end{array}$} & \multirow[t]{2}{*}{ p -value } \\
\hline & PRE & POST & PRE & POST & & \\
\hline EPS(Rs.) & 14.6533333 & 3.17666667 & 2.51865705 & 12.10184008 & -11.476667 & 0.183090672 \\
\hline $\begin{array}{l}\text { Price to Book } \\
\text { Value }\end{array}$ & 1.36333333 & 1.09666667 & 0.273007936 & 0.234591844 & $\begin{array}{l} \\
0.26666667\end{array}$ & 0.26873365 \\
\hline Earnings Yield & 0.06 & 0.01666667 & 0.017320508 & 0.056862407 & $\begin{array}{l}- \\
0.04333333\end{array}$ & 0.275301783 \\
\hline P/E Ratio & 17.54 & 115.06 & 4.079056263 & 188.8822763 & 97.52 & 0.421827569 \\
\hline
\end{tabular}

Source: www.moneycontrol.com, stock-financials.valuestocks.in and author's calculations

\section{MARKET PERFORMANCE RATIOS}

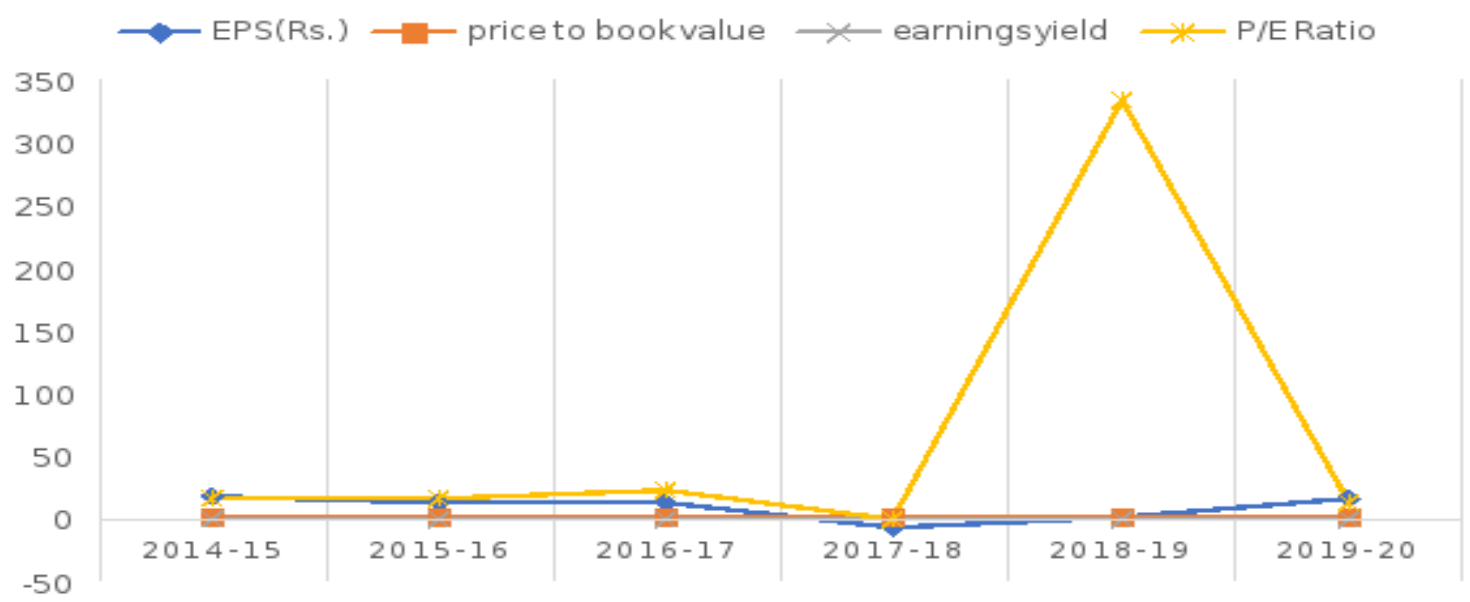

Fig. 2: Market Performance ratios of SBI from 2014-15 to 2019-20 
Interpretation

- EPS has decreased in the years subsequent to the merger. A lower EPS indicates lower possible dividends, thereby, a lower market value. As per the table, though there is a decline in the EPS, it is not statistically significant.

Therefore, the H0 (Null hypothesis) is accepted.

- The Price to Book Value ratio shows a decrease in the years subsequent to the merger. A decrease in Price to Book Value is good for investors. However, the decrease is not statistically significant.

- A slight decrease is observed in earnings yield ratio post-merger, it shows a slight decrease in the return that investors may earn. However, it is not statistically significant.

- There is an increase in the P/E ratio subsequent to the merger, though not statistically significant.

\subsection{Asset Quality Ratios}

Table 4: Pre- and post-merger means of Non-performing Assets of SBI

\begin{tabular}{|l|c|c|c|c|l|l|}
\hline & MEAN & \multicolumn{2}{l|}{ STD. DEV. } & \multicolumn{2}{l|}{$\begin{array}{l}\text { Mean } \\
\text { Difference }\end{array}$} & \\
\hline & PRE & POST & PRE & POST & & \\
\hline Gross NPA & 5.88333333 & 8.19666667 & 1.428577381 & 2.449027018 & 2.313333333 & 0.230470426 \\
\hline Net NPA & 3.21333333 & 3.65666667 & 0.948173683 & 1.837425735 & 0.443333333 & 0.729191352 \\
\hline
\end{tabular}

Source: www.moneycontrol.com and author's calculations

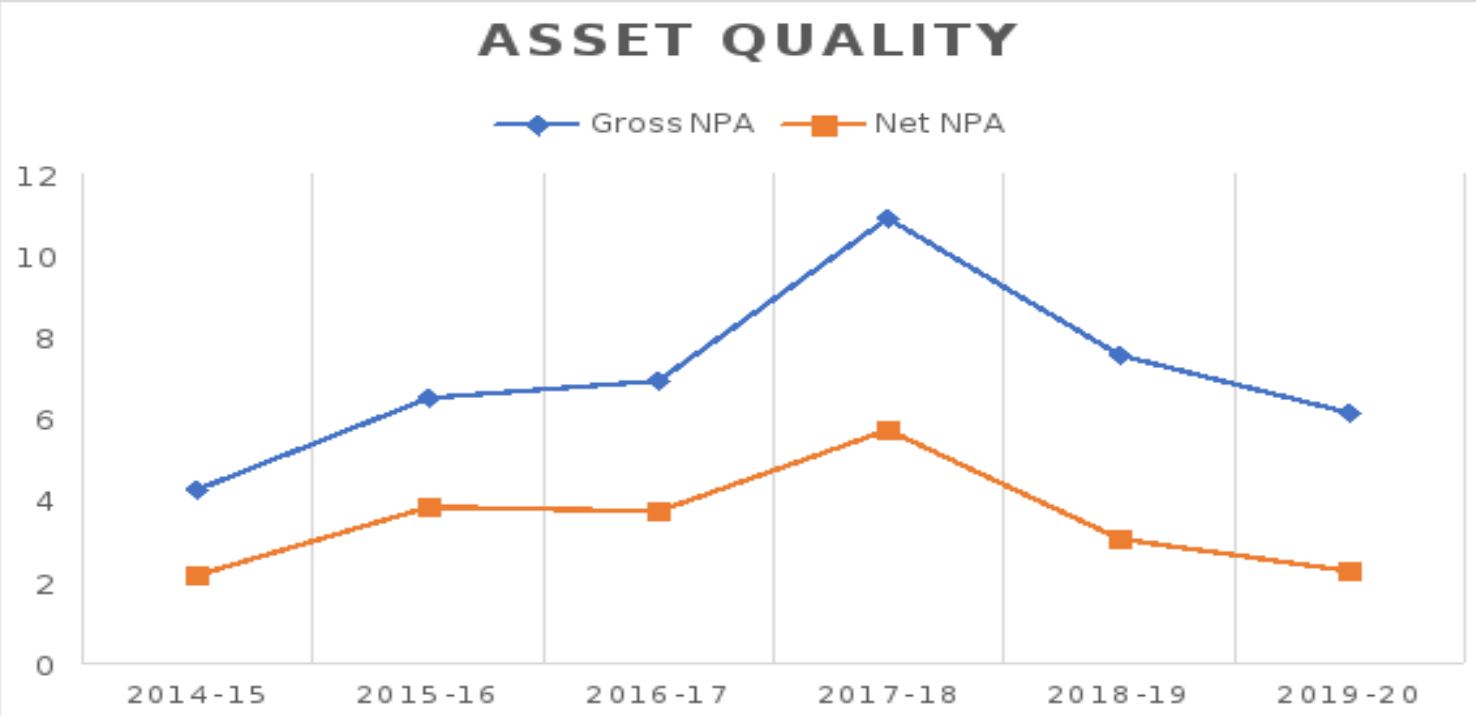

Interpretation

Fig. 3: NPA ratio of SBI from 2014-15 to 2019-20

- Gross NPA has increased post-merger, showing declining asset quality. But it not a statistically significant increase.

- Net NPA is those bad loans for which no provision made in the books. Net NPA gives a better picture of the asset quality. There is a slight increase in the net NPA post-merger, but it is not statistically significant.

- Hence, $\mathrm{H} 0$ is accepted.

\subsection{Liquidity Ratio}

Table 5: Liquidity ratios of SBI 2014-15 to 2019-20

\begin{tabular}{|l|l|l|l|l|l|l|}
\hline & \multicolumn{2}{|l|}{ MEAN } & \multicolumn{2}{|l|}{ STD. DEV. } & $\begin{array}{l}\text { Mean } \\
\text { Difference }\end{array}$ & p value \\
\hline & PRE & POST & PRE & POST & & \\
\hline
\end{tabular}


International Journal of Case Studies in Business, IT, and Education (IJCSBE), ISSN: 2581-6942, Vol. 5, No. 2, August 2021

\begin{tabular}{|l|l|l|l|l|l|l|}
\hline $\begin{array}{l}\text { Loans to } \\
\text { deposits }\end{array}$ & 0.16 & 0.12333333 & 0.03 & 0.02081666 & -0.03666667 & 0.15697509 \\
\hline $\begin{array}{l}\text { Current } \\
\text { ratio }\end{array}$ & 0.33666667 & 0.34333333 & 0.030550505 & 0.04163332 & 0.0066666667 & 0.83401920 \\
\hline
\end{tabular}

Source: stock-financials.valuestocks.in and author's calculations

\section{LIQUIDITY RATIOS}

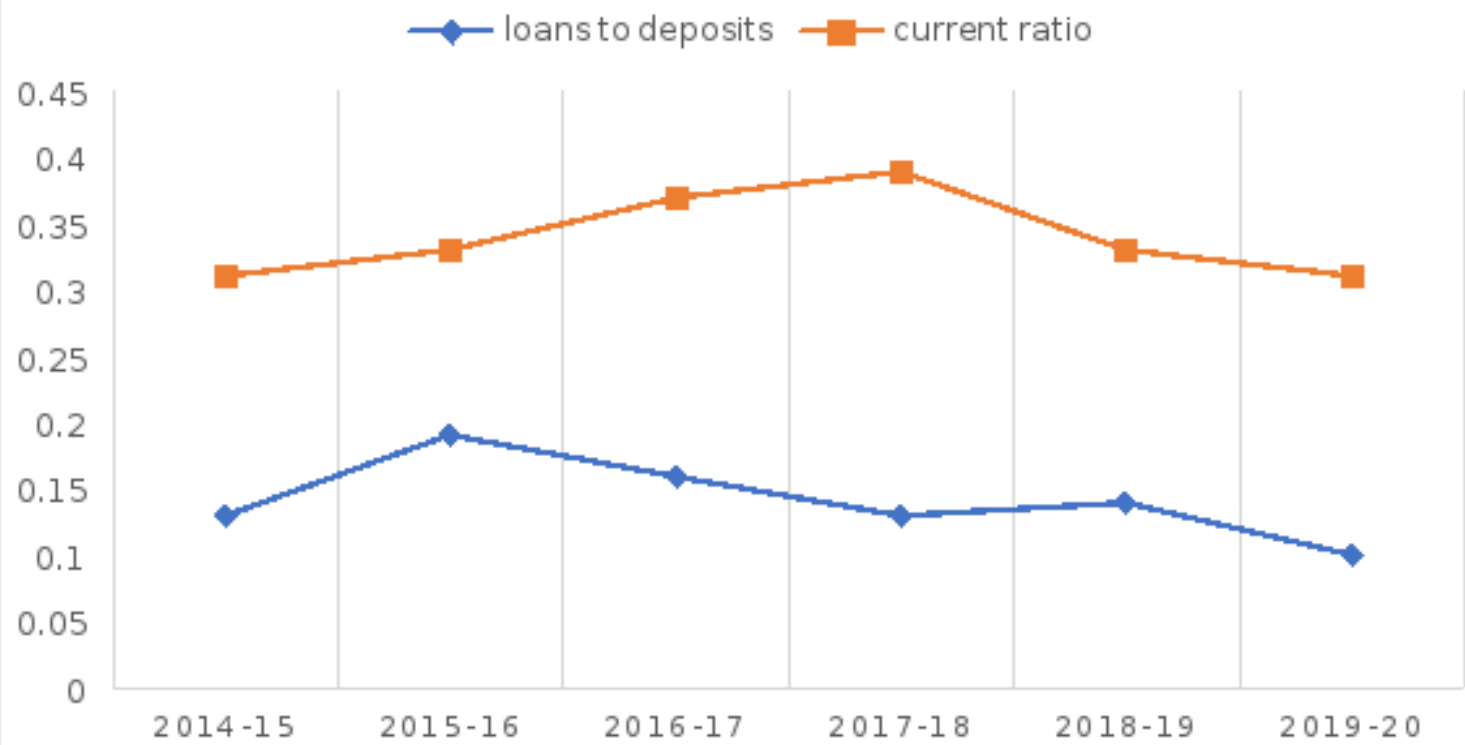

Fig. 4: Liquidity ratios of SBI 2014-15 to 2019-20

\section{Interpretation}

- There is a slight reduction in the loans to deposit ratio, indicating better liquidity in the post-merger years, it can also mean that bank is not lending to its optimum capacity. However, the change is not statistically significant.

- The mean of current ratio is approximately the same both before and after the merger. A slight increase post-merger, indicates a slight improvement in the bank's liquidity position vis a vis it's current obligations.

Therefore, null hypothesis is accepted.

\subsection{Per Employee Ratios}

Table 6: Per employee ratios of SBI 2014-15 to 2019-20

\begin{tabular}{|c|c|c|c|c|c|c|}
\hline \multirow{2}{*}{$\begin{array}{l}\text { Per Employee } \\
\text { Ratios }\end{array}$} & \multicolumn{2}{|c|}{ MEAN } & \multicolumn{2}{|c|}{ STD. DEV. } & \multirow{2}{*}{$\begin{array}{l}\text { MEAN } \\
\text { DIFFERENC } \\
\text { E } \\
\end{array}$} & \multirow[t]{2}{*}{ p value } \\
\hline & PRE & POST & PRE & POST & & \\
\hline $\begin{array}{l}\text { Interest Income/ } \\
\text { Employee }\end{array}$ & $78,05,508.87$ & $\begin{array}{l}6222223.5 \\
6\end{array}$ & 619046.47 & 5477420.1 & $-15,83,285.31$ & $\begin{array}{l}0.644946 \\
4\end{array}$ \\
\hline $\begin{array}{l}\text { Net } \\
\text { profit/Employee }\end{array}$ & $5,31,227.70$ & 110945.25 & $\begin{array}{l}72819.9031 \\
3\end{array}$ & $\begin{array}{l}425382.01 \\
5\end{array}$ & $-4,20,282.45$ & $\begin{array}{l}0.166927 \\
9\end{array}$ \\
\hline $\begin{array}{l}\text { Business/Employ } \\
\text { ee }\end{array}$ & $\begin{array}{l}1,38,13,55,234 . \\
02\end{array}$ & $\begin{array}{l}152832666 \\
2\end{array}$ & $\begin{array}{l}108419706 \\
2\end{array}$ & $\begin{array}{l}134202690 \\
0\end{array}$ & $\begin{array}{l}14,69,71,428 . \\
3\end{array}$ & $\begin{array}{l}0.889836 \\
6\end{array}$ \\
\hline
\end{tabular}

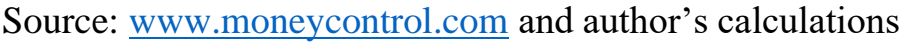




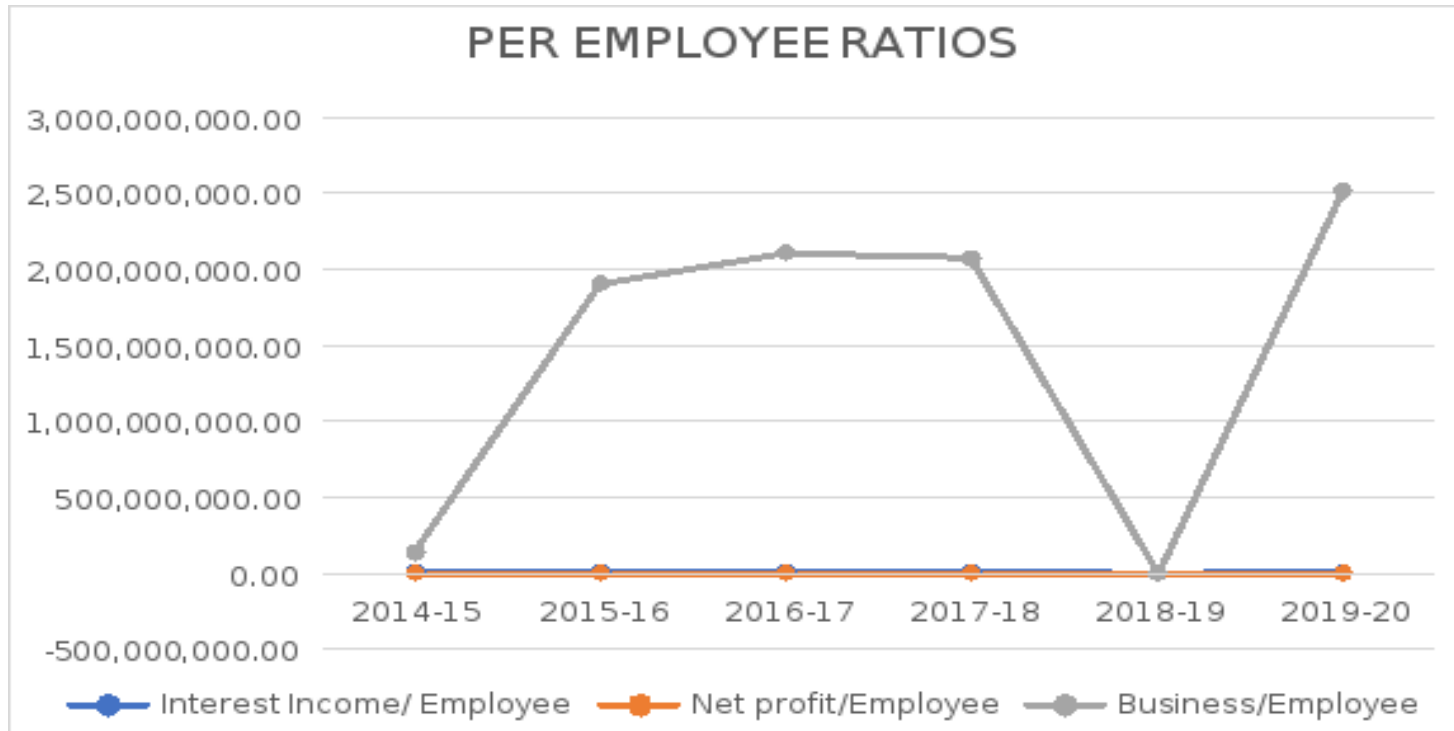

\section{Interpretation}

Fig. 5: Per Employee ratios of SBI from 2014-15 to 2019-20

- The interest income/ employee ratio, which means greater employee productivity and thereby higher profitability has declined post-merger. But the decline is not statistically significant.

- Post-merger, there is a decrease in the net profit per employee ratio. This indicates a decline in the operational efficiency. However, this decrease is not statistically significant.

$\mathrm{So}, \mathrm{H} 0$ is accepted.

- Business per employee ratio is a key indicator of efficiency. Subsequent to the merger, the ratio has increased, indicating that more revenue is generated per employee. However, this increase in Business per employee ratio is not statistically significant.

\section{LIMITATIONS OF THE STUDY :}

- Since the merger has taken place in 2017, financial statements of 3 years each before and after merger and could be analysed for this study.

- This study does not take into account any other economic factors that have influenced the financial performance during the period.

\section{FINDINGS:}

- The study observes that all key performance parameters have declined years after the merger. However, this decrease is not statistically significant.

- The cost to income ratio has increased in the post-merger years. It shows that costs are rising faster than income in the years following the merger. Also, the increase is statistically significant.

- With regard to the market performance ratios, the study finds that $\mathrm{P} / \mathrm{E}$ has increased and $\mathrm{P} / \mathrm{BV}$ has decreased indicating sound market performance post-merger.

However, the EPS and Earnings yield have shown a slight decrease post-merger, indicating a slight decrease in returns, which the investors may earn on their investment.

However, the changes are not statistically significant.

- There is no statistically significant change in the NPA position of the bank.

- About the liquidity position of the bank, there is a slight reduction in the loans to deposit as well as a slight increase in the current ratio indicating an improvement in liquidity position.

- A study of the per employee ratios of the bank shows that even though there is an increase in business per employee ratio, there is no corresponding increase in interest income/ employee ratio and Net profit/ Employee.

\section{RECOMMENDATIONS :}


- An increase in Business/ Employee has not resulted in a corresponding increase in Interest Income/ Employee and even Net Profit/ Employee as expected. Employee productivity has not resulted in real gains for the merged entity. Improved employee productivity can result in better profitability for the bank.

- Asset Quality remains a concern for SBI after the merger too. Improvement in asset quality can lead to better financial position of the bank.

\section{CONCLUSION :}

Starting with the Indra Dhanush 7-point action plan, the Government has embarked on revitalising the Indian banking sector and the SBI merger is an important step in this direction. Following the merger, SBI has become one among the top 50 banks globally. The current study has analysed the profitability, liquidity, NPA position, market performance as well as employee productivity in the 3 years before and after the merger. In the 3 years after the merger, the study finds no improvement in the parameters of financial performance, market performance and asset quality. Also, the cost to income has increased showing decreasing efficiency. However, the liquidity position has improved a little. Though there is an increase in business per employee ratio, there is no corresponding increase in interest income/employee ratio and net profit/employee. The benefits of the mergers may accrue in the medium/long term period.

\section{REFERENCES :}

[1] IBEF. (2021, May 7). Report on the Banking Sector in India. Retrieved from Banking Sector in India: Market Size, Industry Analysis, Govt Initiatives | IBEF on 07/05/2021.

[2] Manikandan, A. (2020, April 1). UPI crosses 100 crore transactions in March despite COVID-19 lockdown and Yes Bank crisis. Economic Times, Retrieved from https://economictimes.indiatimes.com/industry/banking/finance/banking/upi-crosses-100-croretransactions-in-march-despite-covid-19-lockdown-and-yes-bank-crisis/articleshow/ 74933992.cms?utm_source=contentofinterest\&utm_medium=text\&utm_campaign=cppst on 27/05/2021

[3] 3one4 capital. (2020). Retrieved from 3one4 Capital - Early-Stage Venture Capital. Bengaluru, India. on 27/05/2021.

[4] Kaur, J. (2019). A case study on mega merger of SBI with its associate banks and Bhartiya Mahila Bank. Trinity Management Review, 3(3), 1-4.

[5] Edward, A., \& Manoj, J. (2019). Analysis of Pre and Post-Merger Financial Performance of SBI Associate Banks. International Journal of Research and Analytical Reviews, 6(2), 630- 635.

[6] Upadhyay, R., \& Kurmi, M. K. (2020). Recent tie up of SBI with its Associates: A Probe of Pre and Post-Merger Attainment through the Lens of CAMELS Framework. EPRA International Journal of Multidisciplinary Research, 6(10), 198-210.

[7] Kanungo, E., \& Panda, G. P. (2020). Impact of Monetary Policy on the Efficiency of Indian Banking Sector: A Case Study of Pre and Post Merger of SBI. Test Engineering and Management, 83(1), $23481-23493$.

[8] Dhara, P., \& Basu, S. Effect of Merger on SBI and its associates-an Empirical Insight. International Journal of Advances in Engineering and Management, 2(12), 777-784.

[9] Sharma, S., \& Patel, A. K. (2019). A study on performance rating of SBI Group: Camel model analysis. TRANS Asian Journal of Marketing \& Management Research (TAJMMR), 8(5), 36-49.

[10] Healy, P. M., Palepu, K. G., \& Ruback, R. S. (1992). Does corporate performance improve after mergers?. Journal of financial economics, 31(2), 135-175.

[11] Mantravadi, D. P., \& Reddy, A. V. (2008). Post-merger performance of acquiring firms from different industries in India. International Research Journal of Finance and Economics, 22(1), 192-204. 
[12] Singh, S., \& Das, S. (2018). Impact of post-merger and acquisition activities on the financial performance of banks: A study of Indian private sector and public sector banks. Revista Espacios Magazine, 39(26), 25.

[13] Devarajappa, S. (2012). Mergers in Indian banks: A study on mergers of HDFC Bank Ltd and Centurion Bank of Punjab Ltd. International Journal of Marketing, Financial Services \& Management Research, 1(9), 33-42.

[14] Jayaraman, A. R., Srinivasan, M. R., \& Arunachalam, R. (2014). Impact of merger and acquisition on the efficiency of Indian banks: a pre-post analysis using data envelopment analysis. International Journal of Financial Services Management, 7(1), 1-18.

[15] Gupta, H. (2016). Pre- and post-merger financial performance analysis of state bank of India. ZENITH International Journal of Multidisciplinary Research, 6(10), 1-8.

[16] Veena, K. P., \& Patti, S. N. (2016). Financial performance analysis of pre and post-merger in banking sector: A study with reference to ICICI Bank Ltd. International Journal of Management, 7(7), 240-249.

[17] Tanwar, N. (2016). A study on performance analysis of banks in India after mergers \& acquisitions. International Journal of Commerce and Management Research, 2(12), 37- 40.

[18] Patel, R. (2018). Pre \& Post-Merger Financial Performance: An Indian Perspective. Journal of Central Banking Theory and Practice, 7(3), 181-200.

[19] Kumar, M.N.V. (2018). Pre and Post SBI Consolidation and its impact on Financial Performance. Journal of Emerging Technologies and Innovative Research, 5(10), 214-221.

[20] Sreemathi, D., \& Tharmalingam, A. (2018). A Study on financial position of SBI after merger of Associate Banks. International journal of multidisciplinary Research and Modern Education, 4(2), $1-5$.

[21] Ali, F., \& Sharma (2019). A. Pre-Merger and Post-Merger Operating Performance of SBI. International Journal of Recent Technology and Engineering, 8(382), 25- 31.

[22] Economic Times (2017, February 16). Government gives green signal to merger of SBI and its five associate banks. Retrieved from https://economictimes.indiatimes.com/news/economy/policy/government-gives-green-signal-tomerger-of-sbi-and-its-five-associate-

banks/articleshow/57170478.cms?utm_source=contentofinterest\&utm_medium=text\&utm_camp aign=cppst on $27 / 05 / 2021$.

[23] Aithal, P. S. (2017). An Effective Method of Developing Business Case Studies Based on Company Analysis. International Journal of Engineering Research and Modern Education, 2(1), 16-27.

[24] Aithal, P. S. (2017). Industry Analysis-The First Step in Business Management Scholarly Research. International Journal of Case Studies in Business, IT and Education (IJCSBE), 1(1), 113.

[25] Aithal, P. S. (2017). Company Analysis-The Beginning Step for Scholarly Research. International Journal of Case Studies in Business, IT and Education (IJCSBE), 1(1), 1-18.

[26] Vadrale, K. S., \& Katti, V. P. (2018). A comparative study of employee productivity analysis of public and private sector banks in India. Asia Pacific Journal of Research, 1(86), 62-67.

[27] Thangam, D. M., \& Thoushifia, T. (2016). Productivity Analysis of Selected Banks in India. International Journal of Advance Research and Innovative Ideas in Education, 1(3), 308-315.

$* * * * * * * * * *$ 